Japanese Yearbook on Business History - 2000/ 17

\title{
The Activities of General Trading Company Branch Offices in the United States Prior to World War II
}

\author{
Mitsubishi Trading Company
}

\author{
Nobuo KaWABE \\ Waseda University
}

\begin{abstract}
T $\mathrm{N}$ 1941, IMMEDIATELY prior to the start of World War II, Japan's direct investments in the United States amounted to $35,100,000$ dollars. These were in an extremely simple form, all carried out in connection with activities aimed at exporting to the United States goods manufactured by Japanese enterprise and importing into Japan industrial products and raw materials from the United States. ${ }^{1}$

The largest number of investments were made by trading companies; distribution enterprises (including trading companies) ranked

${ }^{1}$ Little research has been done on the investment activities of Japanese businesses in the United States prior to World War II. I made use of the annual reports (from 1942 to 1946) of the Office of Alien Property Custodian and of the Census of Foreign-Owned Assets in the United States (Washington, D.C., 1945) compiled by the United States Treasury Department, Office of the Secretary. Also helpful was Mira Wilkins, "AmericanJapanese Direct Foreign Investment Relationship, 1930-1952," Business History Review 56 (Winter 1982).
\end{abstract}


second in the total amount of money they invested. Almost all of the major Japanese trading companies were making direct investments in the United States in the form of branch offices ( shiten), subbranch offices (shutchōsho), or overseas affiliated companies (genchi höjin); carrying out import and export trade between Japan and the United States, trilateral trade, and business transactions within the United States; and performing the functions that go along with such activities. The role of zaibatsu-related trading companies was significant: in 1939 the four companies of Mitsui Bussan (Mitsui \& Co.), Mitsubishi Shōji (Mitsubishi Trading Co.), Ōkura Shōji (Ōkura Trading Co.), and Asano Bussan (Asano Trading Co.) had offices in such major U.S. cities as New York, San Francisco, Seattle, and Los Angeles and were handling $44 \%$ of the exports from Japan to the U.S. and $57 \%$ of the imports from the U.S. into Japan.

Other trading companies were also active in their own specialized areas. Iwai Shōten, Ataka Shōkai, Ito-Chū Shōji, and Yamanaka Shōten were some that had offices in the U.S. Nippon Menka Kaisha and Goshō Kabushiki Kaisha were two of the cotton trading companies that had established affiliated companies in Fort Worth, San Antonio, and New York in order to secure the same commercial privileges as those enjoyed by U.S. businesses, and from these affiliated companies they opened branch offices and subbranch offices in cotton distribution centers in the southern states.

Supporting the commercial activities of the trading companies were the financial companies and marine transport companies. It was the financial companies (banks and insurance companies) that were the No. 1 Japanese investors in the United States. Banks formed the core of this sector; sixteen of them had branches in the United States, and they provided support to Japanese companies operating within the United States (mostly through commercial financing) and carried on foreign exchange transactions.

Shipping companies, which ranked third in the total amount of investment in the United States, also had branch offices in port cities like New York, San Francisco, and Seattle. These companies were engaged in transporting the merchandise handled in commercial transactions as well as the personnel who carried out such transactions. In contrast to the inroads made by the above types of trade-related businesses, very few manufacturing companies were operating in the 
United States. Two exceptions were Ajinomoto Suzuki Shōten and Sankyō Kabushiki Kaisha.

Thus prewar investment in the United States was being done by trading companies directly involved in Japan-U.S. trade, banks and insurance companies complementing the business operations of the trading companies, and shipping companies in charge of the physical distribution of commercial merchandise. Now, in the past, research has been done from a variety of approaches on the general trading companies that have played an important role in Japan-U.S. trade. Unfortunately, most of the studies on the general trading companies have been based on their domestic operations, and almost no systematic research has been done on their activities overseas. ${ }^{2}$

The following questions can be raised in regard to the overseas activities of general trading companies: 1) Why, and in what way, were specific overseas branch offices and affiliated companies established at specific points in time? 2) How were the establishment of overseas branch offices and affiliated companies related to integration of functions, diversification of the lines handled, and other growth strategies of the general trading companies? 3) Exactly what were the functions and activities of the general trading company sections that were in charge of overseas business operations? 4) What sort of relationship was there between the head office and the branch offices or affiliated companies in charge of overseas business operations? 5) What sort of managerial problems did the branch offices and affiliated companies encounter, and how did they solve them?

In order to answer these questions, this study will analyse the activities in the United States prior to World War II of the general trading company that was right up there with Mitsui \& Co. when it came to representing Japan, a company that also played an important role in Japan-U.S. trade: Mitsubishi Trading Co. ${ }^{3}$

${ }^{2}$ One of the few exceptions is Nobuo Kawabe, "Japanese Business in the United States before World War II: The Case of Mitsubishi Shoji Kaisha, the Seattle and San Francisco Branches," Ph.D. dissertation, Ohio State University, 1980.

${ }^{3}$ Mitsubishi Trading Co. (Mitsubishi Shōji Kaisha in Japanese) was a part of Mitsubishi Gōshi until March 1918. For information on Mitsubishi's Seattle and San Francisco branch offices, I rely on "R.G. 131, Office of Alien Property World War II Seized Process, Mitsubishi Shoji Kaisha (San Francisco and Seattle)" found in the National Record Center in Suitland, Maryland. The materials on the New York branch office were returned by the National Record Center to Mitsubishi, but it is not known what happened to them after 
At the outbreak of the Pacific War in 1941, Mitsubishi Trading Co. had three branch offices in the United States (in New York, San Francisco, and Seattle), a subbranch office (shutchōsho) in Los Angeles, and an agent's office (shutchoin jimusho) in Mexico City-both of the latter under the jurisdiction of the San Francisco branch office. At one time there had also been a subbranch office in Vancouver, Canada, under the jurisdiction of the Seattle branch office. In 1936 the raw silk department had become independent and a branch section of it was established in New York.

Taking into consideration the events that had a major influence on the business activities of Mitsubishi Trading Co. in the United States, I have divided the company's activities (as they developed in all the different offices mentioned above) into four periods: pre-1920; 1920 to $1930 ; 1931$ to 1935 ; and 1936 to 1942 .

THE U.S. ACTIVITIES OF MITSUBISHI GŌSHI (PRE-1920)

Serious Mitsubishi Trading Co. activities in the United States began in April 1916, when Mitsubishi Gōshi established a subbranch in New York in the Equitable Building, 120 Broadway St., registering it under the name of Shirō Naganuma, head of Mitsubishi Gōshi's London branch office.

When World War I broke out in July 1914, Mitsubishi Gōshi had to face a slump in exports, interruption to imports of materials and machinery, and currency exchange problems. Within this economic climate the company was forced to tackle the problems of securing imports of machinery and materials from the advanced industrial countries, acquiring the foreign currencies needed for such purchases by promoting the export of Japanese-made and Chinese-made products, and finding a solution to the problem of exchanging the foreign currencies it acquired. The measure taken to solve these problems was the establishment of a branch office in London, the

that. Therefore, for information on the New York branch office I rely on Ritsugyō bōeki roku [Record of beginnings in trade] (1975), Mitsubishi Shöji shashi [Company history of Mitsubishi Trading Co.] , vol. 1 (1986), and the monthly company publication, Mitsubishi shashi [Mitsubishi bulletin], all of them produced by Mitsubishi Trading Co. 
center of international finance and commerce, in September $1915 .^{4}$ At the same time the company's articles of association were changed (by the addition of commodity sales operations and consignment sales operations), previous contracts with agencies were canceled, and a method of dealing with currency exchange between Japan and England was prescribed (such transactions were to be handled through the company's banking department and settled by the London branch office).$^{5}$

It soon became apparent, however, that the primary purpose for opening the London branch office-the importing of machinery and materials-could not be sufficiently fulfilled in London. The reason for this was the fact that nearly all the products being manufactured by British companies were being consumed domestically by the British government for military purposes, and almost nothing was available for export. ${ }^{6}$

Because of this situation Mitsubishi Gōshi sent Takeshi Kawamura, head of the construction section of the temporary construction department of the iron foundry, to the United States "to order blast furnaces and check on coke ovens." In addition, the market for purchasing machinery and materials for Mitsubishi's shipyards would shift to the United States, and for this reason a subbranch office was set up in New York in April 1916. ${ }^{7}$ The total income of the New York subbranch office was $37,290.80$ dollars in 1917; since the total expenditure was $30,876.34$ dollars, it registered a net profit of 6,414.46 dollars. ${ }^{8}$

In March 1918 the subbranch became independent of the London branch office and became the New York branch office of Mitsubishi Gōshi, directly under the jurisdiction of the head office. Machinery was an important category among the merchandise handled by the New York branch office. Mitsubishi Gōshi's shipyard consigned to it the procurement of machinery for ships and materials needed for shipbuilding. From it were exported to the company's Nagasaki and

${ }^{4}$ Mitsubishi Bulletin 24, p. 2590.

${ }^{5}$ Ibid., pp. 2655 and 2684.

${ }^{6}$ Mitsubishi Bulletin 25, p. 2979.

${ }^{7}$ Ibid., p. 2977.

${ }^{8}$ Ibid., p. 4437. 
Köbe dockyards, and to the contruction department of the temporary iron foundry, machinery of all types. ${ }^{9}$

Another important trade item was tung oil. The company's handling of tung oil went back several years, to the time when, in 1911, Mitsubishi Gōshi's Hankou branch office began dealing in tung oil and sesame. Around 1920 the trade in tung oil really took off, with tung oil being loaded in Hankou and unloaded on the West Coast of the United States, then transported by rail in chartered tank cars for small-lot sales around the country. ${ }^{10}$

Under the jurisdiction of the New York branch office, a subbranch was opened in Seattle in June 1919.11 This was mainly opened in order to supply Japan with the iron and steel needed to build the cargo ships for the U.S. Shipping Board after a Japan-U.S. ship and iron exchange agreement was concluded. But later its principal business involved wheat, wheat flour, and timber. It dealt with very few other items of merchandise.

In 1918 there was a poor rice harvest in Japan, and rice riots took place around the country. The tariffs on wheat imports were lifted, and Mitsubishi Trading Co. took advantage of the situation to embark on wheat trading. The Tokyo branch office and Hong Kong branch office engaged in import sales, the former importing Canadian wheat for Matsumoto Flour Milling (Nittō Flour Milling in 1930), the latter importing U.S. and Canadian wheat flour. ${ }^{12}$

The Seattle subbranch would eventually play a key role in transactions involving United States and Canadian wheat and wheat flour. Also, like the branch offices, its operations were not limited to importing and exporting merchandise; it also acted as an agency for the shipping department of the head office and for Mitsubishi Marine Insurance Co. In addition it carried out loading and unloading operations for the New York branch office. ${ }^{13}$

${ }^{9}$ Mitsubrishi Shōji shashi, vol. 1, p. 110.

${ }^{10}$ Ibid., pp. 149 and 111.

${ }^{1}$ Mitsubishi Bulletin 26, p. 4889.

${ }^{12}$ Mitsubishi Shöji shashi, vol. 1, p. 149.

1s From Kenkichi Imai to Managing Director, "On the Seattle branch audit report," 19 February 1927, R.G. 131 (Seattle), G.F., 1927, no folders, between "Athletic Affairs" and "Fuel Order 391-400." 
After the end of World War I the countries of Europe had exhausted their strength. In their place prospered the United States, and the world economy came to revolve around that country.

Mitsubishi Gōshi's trading department established a miscellaneous goods department in October 1917 and went into the sales and distribution of trade merchandise covering general merchandise made not only within the Göshi organization and related companies but also by other companies. In March 1918 the company hived off all the operations that fell under the business department's jurisdiction into a new company called Mitsubishi Shōji Kabushiki Kaisha (Mitsubishi Trading Co.). ${ }^{14}$

As a consequence of the establishment of Mitsubishi Trading Co. the business operations of Mitsubishi Gōshi's London and New York branch offices were transferred to the new company. This transfer of operations was not to be completed until January 1921, but when it happened, all the employees working at the two branch offices now worked for Mitsubishi Trading Co. ${ }^{15}$

Having started up when Japan's economy was in the middle of a period of feverish activity led by a strong textile industry, the new company naturally was keen on dealing in textiles. Hence, in June 1918 (three months after it was established) it entered a tie-up with Ono Shōten, a venerable old raw silk wholesaler located in Yokohama; using the New York branch office, it embarked on the export of raw silk to the United States. But to improve sales of a speculation commodity when competition was so fierce, running a three-legged race in a tieup was getting the company nowhere fast, so in March 1920 it established Nippon Raw Silk Co. in a merger with Ono Shōten. Nevertheless, this too proved to be a clumsy arrangement, and in June 1922 Mitsubishi Trading Co. was forced to wind down the venture. ${ }^{16}$

In 1924 the original handling right (moto-atsukai-ken) within the company over Mitsubishi coal, a commodity that might by styled the starting point of all of Mitsubishi's trading operations, was handed

${ }^{14}$ Mitsubishi Shōji shashi, vol. 1, p. 157.

${ }^{15}$ Mitsubishi Bulletin 30, p. 5294.

${ }^{16}$ Mitsubishi Shöji shashi, vol. 1, p. 146. 
back to Mitsubishi Mining Co. Mitsubishi Trading Co. would take advantage of this situation to explore new fields to develop. In order to develop these new fields it established branch offices around the world, until a branch office network was completed. As a result of these initiatives, it changed from being a sales organ of Mitsubishi coal and Mitsubishi steel into becoming an independent general trading company. ${ }^{17}$

Meanwhile, the New York branch office was also beginning to deal in new commodities. Thus, for instance, it began in 1918 to deal in ammonium sulphate, a fertilizer. Most of it was secondary-product ammonium sulphate from U.S. Steel Co. and Barrett Co.; because the office already was carrying out iron and steel transactions with U.S. Steel, it made rapid progress in expanding ammonium sulphate transactions as well.18

During this period there were several strategies taken that would have a strong impact on the development of Mitsubishi Trading Co. as a whole, but the one that had the greatest impact on the company's activities in the United States was the decision to move into petroleum trade. In 1923 the company established an internal "Special Committee to Study Liquid Fuel," and on the basis of the committee's report it decided to enter the oil market. In December of that same year it tied up with Associated Oil Co., thus securing exclusive sales rights for heavy oil and crude oil. This led to a change of name for the coal department; in April 1924 it was renamed the fuel department. ${ }^{19}$

In the wake of the incursion into oil transactions, the company sent H. L. Tibbits to San Francisco in November 1924. While he was carrying on negotiations with Associated Oil Co., he also was making preparations for the establishment of a subbranch office, and in February 1926 the company established a San Francisco subbranch under the jurisdiction of the Seattle branch office.

This period was also a period of shedding old skin and reemerging as a modern enterprise. Reflecting on its mistakes during World

\footnotetext{
${ }^{17}$ Yasuaki Nagasawa, Mitsubishi Shöji seiritsu shi no kenkyū [A study of the history of Mitsubishi Trading Co.'s establishment] (Nihon Keizai Hyōronsha, 1990), pp. 179-80.

${ }^{18}$ Mitsubishi Shōji shashi, vol. 1, p. 148.

${ }^{19}$ Ibid., p. 214.
} 
War I, when it expanded operations without any overall control, Mitsubishi Trading Co. organized itself completely, developing control mechanisms to ensure unified control. When the company became independent in 1918, the head office was organized into a general affairs department, a coal department, a metals department, a miscellaneous goods department, and a shipping department. Thus it was made up of one staff department, three line departments, and one auxiliary department. These were reorganized in such a way that, by 1925, there were three staff departments, six line departments (fuel, metals, machinery, foodstuffs, grain fertilizers, and miscellaneous goods), and the one auxiliary department of shipping.

This led to the forming of a managing directors committee, as well as a department heads committee to act as a coordinating body. The system of carrying on transactions was formalized; competition between branch offices and departments was avoided; an effort was made to raise the effectiveness of the entire recovery process. The whole aim of all this was considered to be "nothing else but lifting the fruits of our efforts through a union of minds and a spirit of cooperation that in dealings with other companies does not persist in taking the standpoint of the individual office but sees things in the larger perspective of the interests of the company as a whole."

In the restructuring, main handling shops (moto-atsukai-ten) and handling shops (atsukai-ten) were decided upon for each of the commodities, and profits and losses were concentrated upon the main handling shops. As a control measure, strict credit limits on transactions were set down not only for each branch office but also for each client, and speculative transactions were forbidden. In the area of communication there always is a potential conflict in general trading companies between functional organization (centering around the line departments) and regional organization (centering around the branch offices), but this problem was being solved by channeling things through heads of branch offices and making it possible for the relevant people to know everything that was going on by distributing to every relevant department and location copies of orders and notices. ${ }^{20}$

The machinery that formed the key commodity dealt with by the

${ }^{20}$ For more on such problems of business management, see Kawabe, "Japanese Business in the United States," chapters 3 and 4. 
New York branch office was under the jurisdiction of the metals department for the first couple years after Mitsubishi Trading Co.'s establishment, just as it was in the days when that branch office belonged to Mitsubishi Gōshi, but in April 1920 it became an independent department as a result of the structural reform. In the remainder of this decade the New York branch office would, in connection with the machinery department, acquire exclusive sales rights from representative American firms, and it provided Japanese companies with the commodities of those firms. To handle its machinery transactions the company annually took on more and more of the engineers it needed as it strove to fortify its forces by assigning such engineers as soon as it could to all its locations within Japan and to its principal locations overseas. At the same time, around the middle of 1923 it established a special survey section within the machinery department to embark, with the cooperation of all overseas locations, on a thorough survey of outstanding manufacturers, and then it went ahead with negotiations to acquire agency rights. ${ }^{21}$ Examples of its activities in the first years of the decade are the acquisition of exclusive sales rights for the sale of Goodyear automobile tires in 1920 and the conclusion of agency contracts in 1922 for large machine tools from the U.S. company Niles Tool Workers Co. and for precision machine tools from Pratt \& Whitney. ${ }^{22}$

The New York branch office dealt with other commodities as well. In 1922 it began purchasing Cuban sugar on consignment by Meiji Sugar Mfg. Co., then from May 1924 it carried on the sale of sugar on the New York futures exchange. ${ }^{23}$ Rubber was another commodity it dealt with. Rubber transactions had been transferred to the London and New York branch offices from Mitsubishi Gōshi in 1921, and Mitsubishi Trading Co. added the Singapore branch office to the operations and assigned to each of the three branch offices a person to be responsible for the rubber trade. Speculative limits were set down for each of them, and the company embarked on international rubber transactions with the organic cooperation of the three branch offices.

\footnotetext{
${ }^{21}$ Mitsubishi Shōji shashi, vol. 1, pp. 206-207.

${ }^{22}$ Ibid., pp. 182-85.

${ }^{23}$ Ibid., p. 188.
} 
The venture was not a successful one, however, and in 1929 rubber transactions were abolished in the New York and London branch offices. ${ }^{24}$

The Great Kantō Earthquake of September 1923 had a large impact on the activities of Mitsubishi Trading Co.'s branch offices in the United States. After the earthquake all offices in that country moved into high gear. First of all, the exporting to Japan of steel products meant a dramatic leap in business for all branch offices, especially the one in New York. The Seattle branch office concentrated its efforts more on the exporting of North American timber, wheat, and wheat flour, thus building the foundation for Mitsubishi Trading Co.'s dealings with these commodities. ${ }^{25}$ In addition, in 1926 the Seattle branch office opened an agent's office in Vancouver to deal in Canadian wheat.

About this time Nisshin Flour Milling Co. increased its capital in order to build a new mill in Tsurumi (Yokohama); Mitsubishi Trading Co. took part in the investment of capital in Nisshin, and as a result received orders to purchase overseas flour for Nisshin. It also handled stop-order sales/purchases and consignment purchases, but by the end of 1926 the relationship had progressed to such an extent that it had a consignment contract for exclusive purchasing and even a consignment for futures transactions in the United States and Canada. ${ }^{26}$ Spurred on by these developments, Mitsubishi Trading Co. became a member of the Chicago and Winnipeg exchanges. In addition, the company trialled an incursion into international wheat trading between the London branch office and the New York and Seattle branch offices, beginning in 1928. The trial did not prove successful, so it was soon aborted. ${ }^{27}$

Raw silk was the top export item for Japan prior to World War II. Dealing in this commodity was an important operation for Mitsubishi Trading Co. as well. As we have already seen, the company formed a tie-up with Ono Shōten and set up a company to sell raw silk in the United States, but in June 1922 this company had been dissolved. Now, about March 1922 the Morimura-related Yokohama Raw Silk Co., which

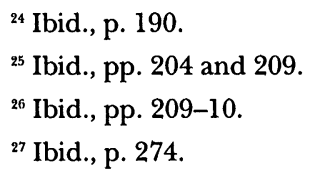


had fallen into funding difficulties and was seeking new capital, sold to Mitsubishi Trading Co. 50,000 preferred stocks; by this means the latter was enabled to take part in the management of the raw silk company. Eventually, with a deterioration in business results after the Great Kantō Earthquake adding to its miseries, Yokohama Raw Silk Co. was forced in July 1924 into dissolution, at which stage Mitsubishi Trading Co. bought it up. Taking over the management of the company in September 1924, it revived the old name used earlier during the days of its tie-up with Ono Shōten, and established Nippon Raw Silk Co., with the head office in Yokohama and a branch office in New York. ${ }^{28}$

During this decade Mitsubishi Trading Co.'s canned goods transactions expanded. Once the company had secured a trading area for canned goods, it separated these operations from the miscellaneous goods department and created a new one, the foodstuffs department. Whereas canned salmon was the main export to England, to the United States canned crab was the mainstream item. In 1923, shipping to the United States consignment goods of Yokoyama Shōkai, it sold through the New York branch office the first canned goods carrying the Mitsubishi symbol on them. In the next year, 1924, it loaned money to the floating crab cannery operations of Yagi Honten Co. and contracted with the latter for exclusive sales of its products, which it shipped to New York and London. This was the first time Mitsubishi Trading Co. formed an exclusive sales relation with a canned crab producer. In 1925 it signed a similar contract with Taisei Fishery Co. ${ }^{29}$

Finally, there were fertilizers. In 1925 American Cyanamide Co. was seeking to expand sales in Japan of its Ammophys, a phosphorus and ammonium sulphate fertilizer. Acting on advice from Konishi Shōten, it laid a nationwide agency network that followed the example of pharmaceutical sales in Japan, choosing Mitsubishi Trading Co. as the principal importer and using its affiliated sales organization. ${ }^{30}$

\section{A TIME OF CONFUSION (1931-1935)}

The stock market plunge in October 1929 and the subsequent panic

$$
\begin{aligned}
& { }^{28} \text { Ibid., pp. } 215-16 . \\
& { }^{29} \text { Ibid., p. } 226 . \\
& { }^{30} \text { Ibid., p. } 227 .
\end{aligned}
$$


in the United States had an effect on Japanese commerce since the United States was at the time Japan's biggest trading partner. The effects began to show in June 1930, and Japan's trade, both imports and exports, fell sharply.

The following year, 1931, was a year in which Mitsubishi Trading Co. was forced to face a business crisis. Not only was it forced to reduce expenses; it also was forced into reducing staff numbers, had to freeze all salaries, and even had to make large cuts in the allowances granted to those working at European and U.S. locations. Despite the economic climate, transactions at the San Francisco office increased steadily, mostly in oil. To keep expenses down, each employee was put in charge of two or three commodity lines. In the wake of the expansion in these transactions, the San Francisco subbranch gradually began to deal directly with each location in order to avoid duplication of office work resulting from going through the Seattle branch office and in order to avoid increasing expenses. When its independence increased sufficiently, it was promoted to branch office status in May 1931.

In an effort to overcome the economic recession of this period, the Mitsubishi Trading Co.'s head office adopted as part of its strategy the tactic of forcing its overseas branch offices to be constantly on the lookout for the possibility of expansion into new commodity areas and trying to increase trade. This was not just an instruction reflecting the will of the head office; Japanese manufacturers whose products were approaching a level at which they could compete with overseas companies were constantly asking Mitsubishi Trading Co. to keep an eye out for the possibility of exporting their products. Among these companies were Asahi Glass Mfg. Co. (window glass), Nippon Kōgaku Kōgyō Kaisha (binoculars, telescopes, optical lenses), Yokokawa Electrical Machinery (electrical gauges and instruments), Kubota Iron and Steel (cast iron pipes), and Nippon Chisso (stiff fertilizer).

The result was that the offices located in the United States were pressured into diversifying the commodities they handled. On the basis of the orders from headquarters and requests from manufacturers, branch offices in the United States first of all conducted test marketing of small quantities of consignment sales, after which they returned 
feedback to the manufacturers in regard to product quality, market directions, prices, and any other problems that arose. ${ }^{31}$

Mitsubishi Trading Co.'s function as a general trading company was most effectively exercised in the miscellaneous goods category of things produced by small-scale businesses (cotton products, for example, or canned goods) rather than in the industrial products of comparatively large-scale companies. Besides simply seeking out markets for these products, the company also had to shoulder a portion of the duties of being an organizer of the industry. The classical case of this sort of responsibility was crab canning. Fishing companies needed funds to set out on fishing expeditions, and their catches were unpredictable, while Mitsubishi Trading Co. had the leeway to systematize the industry because of its financial power. And when it came to exports, as well, in the case of small-scale exports it was ineffective to form export associations or joint sales associations in an effort to avoid the fierce price competition that resulted because the commodity was not one that was open to price discrimination, and so Mitsubishi Trading Co. gradually intervened more and more in the industry's workings.

As chain stores became more widespread in the United States, the company's branch offices put a great deal of effort into distributing canned crab throughout the country and, because it was a relatively recent product, into spreading information on crabmeat recipes. Carrying out intensive publicity campaigns, they regulated the flow of products from the producers right through to the consumers. As can be seen from Table 1, exports of canned goods to the United States did not decrease even though they had to compete with cheaper Russian-made canned crab and the Japanese products were luxury items. The credit for this can be given to the role of the trading companies, especially Mitsubishi Trading Co. ${ }^{32}$

In these canned crab transactions it was the New York branch office that fulfilled the key role of main handling shop. What happened was that everything, down to the most detailed matters, was discussed with the New York branch office, and this office made all

${ }^{\text {s1 }}$ From Momotarō Miyakegawa to head of San Francisco branch office, 1 February 1934.

${ }^{92}$ For more details on the role of Mitsubishi Trading Co. in canned crab transactions, see Kawabe, "Japanese Business in the United States," chapter 5. 


\section{Table 1. Trends in U.S. Imports of Canned Crab (Units: $1,000 \mathrm{lbs} / 1,000$ dollars)}

JAPAN OTHER COUNTRIES TOTALS

Fiscal Year Quantity Value Quantity Value Quantity Value

$\begin{array}{rrrrrrr}1925 & 9,035 & 3,051 & 148 & 61 & 9,183 & 3,112 \\ 1926 & 7,916 & 3,679 & 392 & 91 & 8,308 & 3,770 \\ 1927 & 8,700 & 3,703 & 285 & 81 & 8,984 & 3,784 \\ 1928 & 12,744 & 5,030 & 31 & 13 & 12,775 & 5,042 \\ 1929 & 10,681 & 5,001 & 256 & 111 & 10,937 & 5,112 \\ 1930 & 9,491 & 4,188 & 2,984 & 867 & 12,475 & 5,056 \\ 1931 & 8,391 & 3,449 & 1,871 & 555 & 10,261 & 4,004 \\ 1932 & 6,358 & 2,776 & 2,512 & 835 & 8,870 & 3,611 \\ 1933 & 6,943 & 2,057 & 2,583 & 836 & 9,526 & 2,893 \\ 1934 & 5,232 & 1,747 & 2,150 & 492 & 7,382 & 2,239 \\ 1935 & 8,783 & 3,070 & 2,001 & 427 & 10,784 & 3,497 \\ 1936 & 7,305 & 2,568 & 1,714 & 360 & 9,019 & 2,928 \\ 1937 & 8,103 & 2,909 & 3,054 & 767 & 11,157 & 3,676 \\ 1938 & 5,974 & 2,213 & 1,840 & 528 & 7,814 & 2,741 \\ 1939 & 10,720 & 3,768 & 2,787 & 814 & 13,507 & 4,582 \\ 1940 & 10,709 & 3,269 & 1,162 & 328 & 11,871 & 3,597\end{array}$

Notes: 1) In nearly all the years very small quantities of crab paste and crab sauce are included.

2) As a rule the USSR comprises $85 \%$ or more of the category "Other Countries."

Sources: United States Tariff Commission, Crab Meat, Report No. 57, 2nd ser. (Washington, D.C., 1933), p. 5 and Report No. 141, 2nd ser. (Washington, D.C., 1941), p. 11.

the final decisions about policies and prices and issued instructions on transactions to the Seattle and San Francisco branch offices. ${ }^{33}$ During this five-year period the New York and San Francisco branch offices expanded their commodity lines and were kept quite busy. At the San Francisco branch office the major item it handled continued

${ }^{33}$ Important Documents and Papers Transferred from Nasu to Takeuchi, "Business under Jurisdiction of Marine Products Dept. (Seattle), " 31 March 1935, R.G. 131 (Seattle), F.S. box 484 , loose papers. 
to be oil, and transactions in this commodity increased rapidly after the Manchurian Incident in 1931. It sold crude oil, heavy oil, lubricating oil, and lubricants to the Japanese Navy, Manchū Sekiyu, and Kokura Sekiyu.

The Seattle branch office, in contrast, did not have a large market and was unable to increase the amount of imports of the miscellaneous goods it handled, and it did not have a leading commodity. The only item that continued to keep it busy was timber; during this period the largest market for timber besides Japan was Manchuria. If we look at the percentages of the total volume of Mitsubishi Trading Co. business that each branch office accounted for in the company's 35th, 36th, and 37th terms (from April 1935 to September 1936), we see that the New York branch office's share was $6.3 \%, 5.1 \%$, and $6.4 \%$, respectively; the San Francisco branch office's share was $1.3 \%$, $2.5 \%$, and $1.6 \%$, respectively; and the Seattle branch office's share was $0.4 \%, 0.4 \%$, and $0.6 \%$, respectively. This shows clearly that the New York branch office was fulfilling an important function. ${ }^{34}$

If we turn to the different commodities handled and look at minerals, we find phosphate rock at the top of the list. In 1923 the New York branch office for the first time exported to Japan over 3,000 tons of Florida phosphate rock, then followed this up by exporting an additional 3,200 tons the following year. Still, it did not go into this operation wholeheartedly until it entered into a contract with Phosphate Mining Co. that was in effect an exclusive sales contract. In 1928, through the mediation of the New York branch office, a preferential dealings agreement was reached between the company and a group of producers that centered on Phosphate Mining Co. but also included companies like Swift \& Co. and Coronet Co.

Meantime, the New York branch office had been negotiating with the Florida Phosphate Trade Association over the acquisition of the right to handle exports to Japan; when the above agreement was reached, it stepped up its negotiations, and the Trade Association decided to grant to Mitsubishi the exclusive sales rights that were previously

${ }^{34}$ Letter from Takeuchi to the head of General Affairs Department, "On the Restructuring of This Office," 15 April 1937, and chart comparing volume of business and business expenses of the Seattle branch office, 14 April 1937, R.G. 131 (S.F.), box 669. 
held by Mitsui \& Co. At this point Phosphate Co. also joined the Trade Association and the contract was sealed. ${ }^{35}$

The company also handled a considerable amount of machine tool trade. When the Army arsenal wanted to buy for the Chikusa Kiki Seisakusho a full set of machine tools for manufacturing small arms, Mitsubishi recommended Pratt and Whitney Co. and was given the contract. ${ }^{36}$

The New York branch office conducted transactions involving soybean oil destined for Panama and the West Indies as a substitute for linseed oil and cottonseed oil. The general rule followed by the branch office was that it made sales contracts for round figures with dealers and then left it to them to supply the small-lot customers. ${ }^{37}$ Sales of raw silk in the United States had first been undertaken under the name of Nippon Raw Silk Co. These were now being conducted using the name Morimura, Arai \& Co., which the company had founded as a New York legal body in 1927. This company acted as an agent for Nippon Raw Silk. ${ }^{38}$

Scrap iron transactions expanded during this period. The company had seriously begun to deal in scrap iron imports in 1929, when the iron manufacturing industry underwent rapid development in Japan. Demand for iron and steel rose dramatically especially after the Manchurian Incident. There was a simultaneous yearly increase in the amount of scrap iron being imported-a trend that would go on to exceed the 2,500,000 ton level in 1939. Though the company imported from several sources, its purchases from the United States always amounted to 80 or 90 percent of the total. ${ }^{39}$

After the Manchurian Incident in September 1931 supplies of copper became short. The Suiyōkai ("Wednesday Club") copper sales cartel made a complete about-face and decided to import American copper. Their first purchases were in December 1932, through Mitsubishi Trading Co.: an order for materials from American Smelting \& Refining Co. and Phelps Dodge Corp. ${ }^{40}$

\footnotetext{
${ }^{35}$ Mitsubishi Shōji shashi, vol. 1, pp. 276-77.

${ }^{36}$ Ibid., p. 292.

${ }^{37}$ Ibid., p. 301.

${ }^{38}$ Ibid., pp. 304-306.

${ }^{39}$ Ibid., pp. 353-54.

${ }^{40}$ Ibid., p. 355.
} 
In fertilizers, there was an active influx of overseas ammonium sulphate. In January 1934, representing Japanese manufacturers and the ammonium sulphate compounds guild, Mitsui \& Co. and Mitsubishi Trading Co. entered an agreement with $\mathrm{H}$. Arliss \& Co., the general agent in Japan of the international cartel. According to this agreement the Mitsui and Mitsubishi companies would handle the sales and exports of imported materials. They also won an understanding on exclusive exports of ammonium sulphate produced by Nippon Chisso. Exports of fertilizer from Japan became lively. Mitsubishi Trading Co. conducted a trial of exports of Shōwa Fertilizer (presentday Shōwa Denkō) calcium cyanamide under a cooperative sales arrangement, shipping the product in 1932 and 1933 to the U.S. Pacific Coast. ${ }^{41}$ When it came to calcium superphosphate (superphosphate of lime), in the beginning the company was entrusted only with DaiNippon Artificial Fertilizer Co.'s exports to Los Angeles, but later two other companies, Shōwa Sangyō and Tokkyo Fertilizer, began production, and by handling the exports of these two companies as well the company was able to strengthen its export activities in this area. Exports to the United States were sent to Seattle and San Francisco after an agreement was reached between the Osaka and Seattle offices in June 1931.42

Fish meal was another export item. Exports of the product from the Yokkaichi area had begun in 1929, with a shipment of 4,000 tons to the Pacific Coast. The United States would remain the target of most of the exports of fish meal from Japan, always 50 to 70 percent of the totals. ${ }^{43}$

We can next look at the category of miscellaneous goods. Towards the end of 1930 a company in the Crown Zellerbach group indicated a desire to gain entry into the Orient by means of rayon pulp sales, and in October 1931 Mitsubishi Trading Co., through the New York branch office, concluded an exclusive sales contract with that company (which changed its name to Reyonier Inc. in 1934). ${ }^{44}$

Aluminum was a product Mitsubishi Trading Co. handled right from

"Ibid., pp. 363-66.

${ }^{2}$ Ibid., pp. 367-68.

${ }^{43}$ Ibid., pp. 369-70.

${ }^{4}$ Ibid., p. 371. 
the earliest years of its establishment, supplying the metal to Mitsubishi shipyards. Later it carried on sales as an agent of Asia Aluminum Co., the sales organ of American Aluminum Co., in order to supply the material for Mitsubishi combustion engines. ${ }^{45}$

The U.S. company Corn Products Refining Co. had since 1927 been considering the construction of a factory in Japan because of the increase in demand in Japan for its products. In May 1930 it established Japan Corn Products in Pyongyang in Chōsen for the purpose of producing starch, grape sugar, glucose, and similar products. Mitsubishi Trading Co. invested 3,500,000 yen, or $5 \%$ of the capital. The factory began operations in July 1931 under the management of a Corn Products Refining Co. employee. It made direct sales of the corn starch it produced, and entrusted Mitsubishi Trading Co. with exclusive sales (3\%) of corn sugar and glucose within Japan, in Chōsen, and in Taiwan. A steep rise in the price of raw materials, however, led to a slump in sales, and in January 1937 the head office in the United States not only consigned production and sales to Japan Corn Products but also handed over to Mitsubishi Trading Co. exclusive sales even of the products imported from the parent company itself. ${ }^{46}$

Out of all the munitions items like planes, naval vessels, and tanks, planes were the one item in particular in which there was increased production resulting from the drive from 1932 towards domestic production and in which there was a need for factories capable of speedy response to the unremitting demands emanating from the Army and Navy. Mitsubishi Trading Co. was continually entrusted with signing contracts for production rights for research purposes on behalf of Mitsubishi Aircraft Co., and also with the purchasing of whole aircraft, instrument attachments, and parts. From the United States the company purchased Hornet engines from Pratt \& Whitney and complete NA16-4 trainers from North American. ${ }^{47}$

Aircraft production inevitably necessitated a large increase in the production of machine tools. Mitsubish Aircraft's Nagoya Works and the Mitsubishi Shipbuilding and Engineering Co. (from June 1934 Mitsubishi Heavy Industries) Kōbe Dockyard underwent a huge

${ }^{45}$ Ibid., p. 381.

${ }^{46}$ Ibid., p. 283.

${ }^{47}$ Ibid., pp. 396-97. 
expansion in plant and equipment, and in 1933 the company first was entrusted by Mitsubishi Aircraft's Nagoya Works with the purchasing of large amounts of imported machine tools, and this was changed to bulk consignment purchasing from 1937 on.

Nissan Motor Co., which from 1933 had had Mitsubishi Trading Co. carrying out consignment purchasing transactions involving imported American-made machine tools, built a new plant in 1936 in Yokohama, and on this occasion it had Mitsubishi purchase and deliver for use in the new plant a full set of equipment for manufacturing automobiles from the Graham-Paige Co. in America: machine tools and instruments, partly finished goods, parts, and other materials. The company also purchased for the Fushun Coal Mine of the South Manchuria Railway in 1934, and delivered to it, oil cracking apparatuses made by the American company UOP, for the purpose of cracking oil shale. ${ }^{48}$

Mitsubishi Trading Co. played an important role in the exporting of domestically made machinery. This was especially true in regard to textile machinery. From 1932 on it was in charge of exports to the United States of caustic soda reclaimers made by Asahi Bemberg Silk Thread (the Asahi dialyzers), concluding agreements with Dupont and Shenandoah Rayon Co. for approximately fifty of the apparatuses. Cast-iron pipe joints made by Tobata were exported under an exclusive arrangement whereby Mitsubishi Trading handled the shipping from 1932 on. From 1934 the company also exported to the United States wire rope made by Tokyo Wire-Rope Mfg. Co. Finally, it handled the sales overseas of Itsumi Works slide rules under an exclusive arrangement that went back to 1927.49

In 1933 the company added cotton transactions to its dealings with Persia over claims for damages. Because Kanebō and Tōyōbō agreed to make use of Persian cotton, the opportunity finally arose to end speculative importing and to deal regularly in cotton. The company went into handling cotton in a big way when it had to handle Indian and American cotton. At the time of the panics in the early years of the Showwa period the traditional cotton merchants burnt their fingers, and the three major cotton merchants, Toyō Cotton, Nippon Cotton, and Goshō showed a tendence to control their excessive

\footnotetext{
${ }^{48}$ Ibid., pp. 408 and 410.

${ }^{49}$ Ibid., pp. 412-14.
} 
speculative competition. Mitsubishi Trading Co. saw that the time was ripe to embark on cotton transactions, and in October 1935 the Board of Directors decided on beginning cotton trading. ${ }^{50}$

Meantime, Nippon Raw Silk, which had been doing well for some time, started losing money in 1932. For this reason, and because there had long been criticism of the company's policy of letting it remain a separate organization, in April 1936 the company established a new raw silk department that took over the operations and all the rights and obligations of Nippon Raw Silk. ${ }^{51}$

\section{TOWARDS THE WAR (1936-1942)}

From the time of the Manchurian Incident in 1931 the Japanese economy had gradually been saddled more and more with wartime controls, and this tendency took on a more obvious form after the outbreak of Japanese-Chinese hostilities. At the same time, relations between Japan and the United States deteriorated rapidly, foreign exchange control was tightened, competition among trading companies intensified, and there was a shortage of cargo ships.

The activities of Mitsubishi Trading Co. within the United States were naturally affected by all these trends. As the Japanese government widened the grip of wartime economic controls, there was a rapid change in the transaction patterns of branch offices. On the one hand, work involving the exporting to Japan of war-related materials such as oil (petroleum) and scrap iron increased, while on the other hand exports from Japan decreased, the result of shortages of raw materials for Japanese export-oriented companies, the continuation of the economic recession in the United States, and Japanese-government controls on the export of items such as fertilizer.

The New York and San Francisco branch offices managed to cope with these changes in circumstances, but transactions at the Seattle branch office fell off and the inefficiency of maintaining that office became obvious (see Tables 2 and 3). To make matters worse, the head of the Seattle branch office, Shun'ichi Takeuchi, was also the head of the San Francisco branch office, and he was permanently resident

\footnotetext{
${ }^{50}$ Ibid., pp. 419-20.

${ }^{51}$ Ibid., p. 421.
} 


\begin{tabular}{|c|c|c|c|c|c|}
\hline \multirow[b]{2}{*}{ Period } & \multicolumn{4}{|c|}{$\begin{array}{l}\text { Table 2. Volume of Contractual Agreements of Seattle Branch Office } \\
\text { (Unit: } 1,000 \text { dollars) }\end{array}$} & \multirow[b]{2}{*}{ TOTALS } \\
\hline & IMPORTS FROM JAPAN & EXPORTS TO JAPAN & U.S. TRANSACtIONS & Third-Country Trade & \\
\hline 36 (Oct. '35-March '36) & $2,900(76.5 \%)$ & $390(10.3 \%)$ & - & $500(13.2 \%)$ & 3,790 \\
\hline 37 (April '36-Sept. '36) & $2,610(63.2 \%)$ & $720(17.4 \%)$ & - & $800(19.4 \%)$ & 4,130 \\
\hline 38 (Oct. '36-March '37) & $3,600(55.5 \%)$ & $790(12.2 \%)$ & $1,350(20.8 \%)$ & $750(11.6 \%)$ & 6,490 \\
\hline 39 (April '37-Sept. '37) & $4,830(80.5 \%)$ & $680(11.3 \%)$ & - & $490(8.2 \%)$ & 6,000 \\
\hline 40 (Oct. '37-March '38) & $2,865(69.0 \%)$ & $245(6.0 \%)$ & $1(0.02 \%)$ & $1,008(24.5 \%)$ & 4,119 \\
\hline 41 (April '38-Sept. '38) & $538(27.0 \%)$ & $263(13.2 \%)$ & $39(2.0 \%)$ & $1,156(57.9 \%)$ & 1,996 \\
\hline 42 (Oct. '38-March '39) & $2,225(57.0 \%)$ & $323(8.3 \%)$ & $56(1.4 \%)$ & $1,302(33.3 \%)$ & 3,906 \\
\hline 43 (April '39-Sept. '39) & $3,435(57.0 \%)$ & $798(13.2 \%)$ & $13(0.2 \%)$ & $1,781(29.6 \%)$ & 6,027 \\
\hline 44 (Oct. '39-March '40) & $6,379(69.7 \%)$ & $840(9.2 \%)$ & $287(3.1 \%)$ & $1,653(18.1 \%)$ & 9,159 \\
\hline 45 (April '40-Sept. '40) & $5,441(46.6 \%)$ & $503(4.3 \%)$ & $233(2.0 \%)$ & $5,510(47.1 \%)$ & 11,687 \\
\hline 46 (Oct. '40-March '41) & $3,980(69.9 \%)$ & $367(6.4 \%)$ & $175(3.1 \%)$ & $1,175(20.6 \%)$ & 5,697 \\
\hline 47 (April '41-Sept. '41) & $793(10.1 \%)$ & $235(3.0 \%)$ & $7(0.1 \%)$ & $6,826(86.9 \%)$ & 7,861 \\
\hline \multicolumn{6}{|c|}{$\begin{array}{l}\text { Source: Seattle Branch Office, "Business Reports by Location" in the } 37 \text { th to } 48 \text { th periods, } \\
\text { R.G. } 131 \text { (Seattle), F.S. 1921-41, box } 484 \text {. }\end{array}$} \\
\hline
\end{tabular}


Table 3. Volume of Contractual Agreements of San Francisco Branch Office (Unit: 1,000 dollars)

PERIOD

35 (April '35-Sept. '35)

36 (Oct. '35-March '36)

37 (April '36-Sept. '36)

38 (Oct. '36-March '37)

39 (April '37-Sept. '37)

40 (Oct. '37-March '38)

41 (April '38-Sept. '38)

42 (Oct. '38-March '39)

43 (April '39-Sept. '39)

44 (Oct. '39-March '40)

45 (April '40-Sept. '40)

46 (Oct. '40-March '41)
IMPORTS FROM JAPAN

$$
\begin{array}{r}
4,003(32.9 \%) \\
3,982(28.8 \%) \\
4,068(35.5 \%) \\
4,914(19.8 \%) \\
3,019(14.2 \%) \\
3,343(12.4 \%) \\
2,707(9.0 \%) \\
1,798(4.3 \%) \\
2,402(5.5 \%) \\
2,260(4.1 \%) \\
1,454(3.0 \%) \\
1,339(2.0 \%)
\end{array}
$$

EXPORTS TO JAPAN

U.S. TRANSACtions

ThiRd-Country TRADE

Totals

$7,250(59.6 \%)$

$$
352(2.9 \%)
$$

$8,388(60.5 \%)$

$143(1.0 \%)$

$561(4.6 \%)$

$1,337(9.7 \%)$

$985(8.6 \%)$

$26,751(88.5 \%)$

36,231 (85.8\%)

$35,116(80.3 \%)$

$42,087(77.0 \%)$

$38,608(80.2 \%)$

$60,084(89.1 \%)$
2,127 (8.6\%)

$1,729(8.2 \%)$

2,387 (8.8\%)

$656(2.2 \%)$

$125(0.4 \%)$

$159(0.4 \%)$

$84(0.3 \%)$

$286(1.3 \%)$

$4,018(9.5 \%)$

$6,215(14.2 \%)$

$10,330(18.9 \%)$
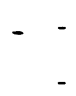

$8,048(16.7 \%)$

$5,978(8.9 \%)$
12,166

13,850

11,469

24,827

21,211

27,004

30,239

42,206

43,733

54,677

48,110

67,401

Source: San Francisco Branch Office, "Monthly Reports on Volumes of Contractual Agreements," periods 35 and 36: R.G. 131 (S.F.), box 689; periods 37-38, R.G. 131 (S.F.), box 616. 
in San Francisco. As a result, for almost twenty years an American who had worked for Mitsubishi Trading Co. was the vice head of the Seattle branch office, and he functioned as the person responsible for dayto-day matters, and communication between the head office and the Seattle branch deteriorated. ${ }^{52}$

Whenever transactions were carried out, in order to avoid the kinds of problems that arise from inadequate knowledge about local ways of doing things and local culture, it was standard Mitsubishi Trading Co. practice for Japanese executives in U.S. branch offices to entrust routine administration to locally hired employees. On the other hand, full-time Japanese employees were in all the group head positions in the branch offices, supervising and managing the local employees, bridging the communication gap between Japan and the United States, and ensuring that this communication gap was not introduced into dealings between the head office and branch offices, or between one branch office and another. This was how the company converted international transactions in the marketplace into internal transactions within the company.

As the environment gradually became more difficult, the branch offices in the United States tried new strategies. The first of these was that they attempted to offset the drop in transactions with other countries besides Japan and the drop in imports from Japan by developing trilateral trading and transactions within the United States itself. One example of this was the opening of a small office in Mexico City in August 1940, whose principal dealings were in rayon and mercury. ${ }^{53}$ To expand activities within the United States itself, a Los Angeles subbranch office was opened in February 1940. The hope was to develop transactions in petroleum, metals, machinery, foodstuffs, chemicals, timber, fertilizers, and miscellaneous goods. As it turned out, however, the subbranch office was unable to achieve much development in this area.

${ }^{52}$ Letter from Shun'ichi Takeuchi to head of General Affairs Department, "On the Restructuring of This Office," dated 6 April 1938, Private Letter from Wasaburō Murase to Takeuchi (around 1937), and Letter from Takeuchi to head of General Affairs Department, "On the Restructuring of This Office," dated 15 April 1938, R.G. 131 (S.F.), box 669.

${ }^{53}$ Letters from Takeuchi to head of General Affairs Department, "On the Dispatching of a Representative to Mexico," dated 11 and 13 July 1939, R.G. 131 (S.F.), box 621. 
The second strategy adopted was the formation of strategic alliances with other companies. This move was spurred on by two factors: the increasingly fierce competition with Mitsui \& Co., and the control of foreign exchange and business activities being exerted by the Japanese government. And so, for example, to alleviate the problems of high freight rates and insufficient cargo space availability, the company concluded a special agreement with Nippon Yūsen that secured for it special freight rates and cargo space. Similarly, to counteract the building of a beer plant in Manila by a joint operation of Mitsui \& Co. and Dai-Nippon Beer, Mitsubishi Trading Co. tried to build a Kirin Beer plant in Hawaii in a joint venture with Kirin Beer and local capital. Because of the tight control over foreign exchange, it was unsuccessful in bringing this project to fruition, but this idea was a harbinger of the model that became very general after World War II: a joint venture in which the general trading company, a producer, and local capital would combine efforts.

The tight controls on foreign exchange forced Mitsubishi Trading Co., Tōyō Kōhan, and Tōyō Seikan into setting up a new financial system, according to which the proceeds from sales of canned goods whose materials Mitsubishi Trading C. had itself imported would be pooled by the New York and London branch offices in order to pay for the raw materials. ${ }^{54}$

The company renewed serious dealings in cotton, the commodity that was the progenitor of all its import activities, in 1935; in 1938 it tied up with Hamilton Co. for supplies of California cotton, and it lifted profits in Texas cotton dealings (mainly in the New York branch office) through coming to terms with shippers, so that by 1940 it carried on purchases of 57,000 bales of cotton, lifting it to a ranking within the top five companies in Japan. ${ }^{55}$

The sale of canned marine products, especially salmon and crab meat, was stimulated during this period by exports aimed at obtaining foreign currency, and this was assisted by the stocking up of foodstuffs that accompanied fears of war in the countries of the West, so that in 1939, the year World War II began in Europe, sales in these

\footnotetext{
${ }^{54}$ More on this move can be found in Kawabe, "Japanese Business in the United States," chapter 7 .

${ }^{55}$ Mitsubishi Shöji shashi, vol. 1, p. 481.
} 
canned goods reached record-breaking proportions. Mitsubishi Trading Co. became the largest exporter of canned marine products in Japan. It sold its canned goods in the United States to two types of clients: Japanese companies located in the United States, such as Nozaki, Dōmoto, and Komada; and several dozen brokers scattered throughout the country who bought directly from Mitsubishi Trading Co. ${ }^{56}$

As we saw earlier, a raw silk department was set up in April 1936. Since $90 \%$ of the exports of raw silk were headed for the United States, in May a New York branch of the raw silk department was established, and it began operations immediately. Unfortunately, however, this did not lead to a subsequent increase in the exports of raw silk to the United States. ${ }^{57}$

From the autumn of 1936 Mitsubishi Trading Co. and Mitsui \& Co. each shared half of the trade in U.S. pig iron. ${ }^{58}$ Imports from the United States were carried out in a concentrated manner, the companies from which the purchases were made being mostly U.S. Steel, and companies like Bethlehem Steel, Pittsburgh Steel, and Republic Steel..$^{59}$ Nonferrous metals and Canadian copper were purchased the same way, with Mitsubishi working with Mitsui in purchasing these commodities. ${ }^{60}$

The machinery department of Mitsubishi Trading Co. did its best to import the best steel-making and machine tool machinery available overseas; working closely with Mitsubishi Heavy Industries, Mitsubishi Electrical Engineering Co., and Mitsubishi Kakōki, it strove to supply the products of these companies to all its domestic and Manchurian branch offices; it also provided capital and managerial assistance, as well as training assistance, to middle-level enterprises that were customers of, or had cooperative arrangements with, Mitsubishi Trading Co. or these other Mitsubishi companies. ${ }^{61}$

Realizing that the trend in Japan's iron and steel industry was changing from German products to U.S. products, the company

\footnotetext{
${ }^{56}$ Mitsubishi Trading Co., Record of Beginnings in Trade (see note 3), p. 580.

${ }^{57}$ Mitsubishi Shōji shashi, vol. 1, p. 499.

${ }^{58}$ Ibid., p. 508.

${ }^{59}$ Ibid., pp. 508-10.

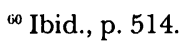

${ }^{61}$ Ibid., p. 517.
} 
formed a tie-up with Mesta Co., the second largest manufacturer of steel machinery in the United States, in 1936, and through it ordered and delivered strip mills until America's enforcement of approvals for exports of machinery to Japan in June 1940.62

From the summer of 1938 until the end of 1939, the Japanese Army and Navy sent trade groups to the United States and Europe to purchase machine tools and engaged in a machine tool buying frenzy. Mitsubishi Trading Co. mobilized all of its overseas offices to cooperate in this exercise, and it was able to handle contracts worth a total of 43,000,000 yen (split almost evenly between the U.S. and Europe). At the same time, the company made purchases of large amounts of imported machine tools (including secondhand items) for Mitsubishi Heavy Industries, Mitsubishi Electrical Engineering, Mitsubishi Kakōki, and other Mitsubishi group companies, as well as for Nissan Motor Co., Dai-Nippon Heiki, Manchuria Industrial Development and its subsidiary Dōwa Motor Co., Manchuria Aircraft Mfg. Co., and Dong Bian Dao Development Co. ${ }^{63}$ Aviation fuel production equipment was another area of activity: towards the end of 1938 the company ordered from UOP an entire isooctane plant, which it delivered to Mitsubishi Oil Co.'s Kawasaki oil refinery. ${ }^{64}$

As part of the development of Manchuria, the Songhua Jiang power plant (500,000 kilowatts) was built in Jilin, and for this project the company put in a combined order for a waterwheel made by the Swiss company Escherweiss and a dynamo made by Westinghouse Co. of the U.S. ${ }^{65}$

Despite the fact that demand by the South Manchuria Railway Co. increased, it could not be met by Japanese manufacturers, whose ability to supply goods was at a low ebb because of various restrictions imposed on their operations. For this reason the South Manchuria Railway decided to purchase secondhand rolling stock. In response to the railway's requests, Mitsubishi Trading Co. purchased from the Pennsylvania Railway Co., which was moving into electrification,

\footnotetext{
62 Ibid., pp. 519-20.

${ }^{63}$ Ibid., pp. 521-22.

${ }^{64}$ Ibid., p. 523.

${ }^{65}$ Ibid., p. 527.
} 
fifteen of its no longer needed steam engines, which were then delivered to South Manchuria Railway. ${ }^{66}$

In spite of all the diligent efforts of the branch offices in the United States, the economic situation became even worse. In July 1938 the U.S. government had introduced what was called "a moral embargo." Next, in July of the following year notice was given to Japan that the maritime treaty between Japan and the United States would be invalidated in January 1940.

To deal with this situation, in 1941 the New York branch office tried to set up a canned goods distributor as an overseas affiliated company and thus avoid anti-Japanese sentiments. The San Francisco branch office purchased a dummy company in Panama named Compania Colonial de Navigation as a means of deliverying motorized sailboats to Nichi-Ro Gyogyō. ${ }^{67}$ Nevertheless, Japanese-American relations had deteriorated so much that measures like these were to no avail. When the Japanese forces invaded French Indo-China in July 1941, the U.S. government ordered all Japanese assets in the United States frozen; the next month it placed an embargo on exports of strategic materials to Japan and carried out an economic blockade of Japan. Its supply of military resources (oil in particular) completely cut off, Japan went on to start the war in December.

After the attack on Pearl Harbor the U.S. government confiscated the assets and books, ledgers, etc. of all Mitsubishi Trading Co. offices in the United States. When the Office of Alien Property Custodian was instituted in 1942, all these things were transferred to this body and put in order by a few of the company's American employees; the majority of the company's assets were sold off by the end of 1942, and the curtain fell on the U.S. activities of Mitsubishi Trading Co. ${ }^{68}$

\section{CONCLUSION}

The above represents a historical review of the activities of Mitsubishi

${ }^{66}$ Ibid., p. 529.

${ }^{67}$ Kawabe, "Japanese Business in the United States," chap. 7.

${ }^{68}$ Robert A. Nelson, Representative, Alien Property Custodian to A. L. Stone, Office of Alien Property Custodian, 24 November 1942, R.G. 131 (S.F.), Liquidation File, February 1940 to May. 1943, "Letters Sent Out by R. A. Nelson." 
Trading Co. in the United States. In line with the presentation of the problem made at the beginning of this study, we can now bring together the analytical fruits of this review.

When one looks at the development of the general trading company and its overseas activities, the first thing one has to do is look at these things in connection with the development of the Mitsubishi zaibatsu. Mitsubishi Trading Co. was a member of a zaibatsu made up of several companies. The general trading company imported raw materials and exported manufactured goods, thus fulfilling an integrating function. Mitsubishi Trading Co. really was the transaction arm of Mitsubishi zaibatsu companies. Member companies of the zaibatsu that were ignorant of how to carry on transactions with overseas companies did not themselves control the flow of manufactured goods in dealings with overseas markets, they entrusted that function to a fellow member of the zaibatsu: Mitsubishi Trading Co.

For Japan, a country poor in raw materials and with a narrow market, the country's general trading companies had the important role of finding overseas sources of supply and overseas markets for other companies in their respective zaibatsu as well as for other companies not in the same zaibatsu group. Consequently, diversification of the commodities handled was very closely connected with the development of overseas offices. Thus, for example, Mitsubishi Trading Co. opened the New York subbranch office in order to deal with machinery, and it opened the Seattle subbranch office in order to sell steel to Japanese shipbuilding companies, especially the Mitsubishi shipyards. Similarly, in order to handle the petroleum products needed by Japan's Navy, a huge and stable market in Japan, the company's San Francisco subbranch office was opened.

Along with diversification, another reason Mitsubishi Trading Co. had for increasing the number of overseas offices was that in this way it could internalize some of the international trade that the importers and exporters in the receiving country had traditionally been in charge of. By internalizing international trade, the company could avoid the problems that arise from communication and cultural gaps and was able to engage in business. International transactions involved transactions between the head office and a branch office (exporting and importing) or between branch offices (trades between two countries other than Japan). By entrusting routine 
operations to local employees Mitsubishi Trading Co. reduced the risks of international transactions, and Japanese employees oversaw the local employees.

Once these internalized transactions are firmly in place, a general trading company is able to increase such transactions and to increase the number of overseas branch offices. This enables the trading company to hunt out the cheapest raw materials and the most profitable markets anywhere in the world. The trading companies have already been practising the ideas being discussed nowadays of economies of scope and optimum-site production.

And yet in reality there arose many problems to prevent the development of the general trading company. Thus, for example, there was the danger that these branch offices and the business division would compete with each other as independent operating units-the danger, in other words, of uneconomy of scale. Mitsubishi Trading Co. developed an organizational structure that was decentralized along the lines of the commodities handled (business division) and regions (overseas branches). In order to avoid competition between the business division and branch offices, the company introduced the system of main handling shop and handling shop.

In order to have effective control over the overseas branch offices and the company as a whole, Mitsubishi Trading Co. established limits on transaction amounts and credit. It also continually improved all its communication and reporting systems; as a result, the head office could know how the branch offices were performing and could make adjustments. For a trading company, obtaining up-to-date and reliable information was one of the most important requirements for regulating the activities of branch offices.

A stable and regular flow of commodities was needed in order to have effective control of internalized transactions. Trading companies have been said to deal in all sorts of commodities, "from ramen to missiles." In general, the trading companies have given the impression that they have handled an endlessly wide variety of goods. When one studies the development of a trading company like Mitsubishi Trading Co., however, it becomes clear that the company restricted the commodities that it handled to those whose flow from supplier to consumer could be effectively controlled. In order to achieve a stable and 
regular flow of commodities, a general trading company had to fulfill all sorts of secondary functions.

The commodities handled by Mitsubishi Trading Co. were: 1) raw materials in which economies of scale were at work in their being supplied from a large-scale supplier to a large-scale consumer, as seen in the classic case of oil (petroleum); 2) high-priced manufactured goods with high-quality composition, such as machinery and plant equipment (in these cases Mitsubishi Trading Co.'s gathering of information on manufacturers around the world and its financial services were a necessary element); 3) miscellaneous goods that would have many purchasers and were liable to little damage, such as canned crab (in these cases the company aimed at organizing the supply sources by providing funds for their fishing operations and extending to them export credit). In order to secure their supply sources the company secured exclusive purchase rights and exclusive sales rights. In this way the company controlled the flow of commodities from production to consumption. It is believed that in its handling of the above commodities the company most effectively fulfilled its trading company functions.

It was in these ways that Mitsubishi Trading Co. created the management structure it needed to internalize the world market and to regulate the flow of commodities. It carried out a combination of functions of providing funds, concluding general-agency contracts, arranging for cargo vessels, collecting market information, and even receiving groups of people from Japan on inspection trips. It was through firmly establishing such a system and such functions as these that Japan's general trading companies gradually came to control the trade between Japan and the United States that had once been controlled by foreign traders. Each of the branch offices of Mitsubishi Trading Co. functioned as a part of this one vast system. 